\title{
CLINICAL AND EXPERIMENTAL STUDIES ON THE ANTIDIURETIC EFFECT OF THE LABYRINTHINE STIMULI
}

\author{
By \\ K. MASUDA \\ From the Department of Oto-Rhino-Laryngology, Faculty of MEdicine, University of Tokyo \\ (Director: Prof. I. Kirikae)
}

The author studied the influence of the labyrinthine stimuli upon waterdiuresis of the normal water-loaded man. Oliguria was seen in seven subjects out of seventeen when theordinary clinical stimuli (rotation or calorisation) were giver. But when the subjects shaked the head periodically ( $\mathrm{T}=4 \mathrm{Sec}$.) for about five minutes during the rotation, urinary flow was. always reduced remarkably.

On the other hand, waterdiuresis in twenty patients of Ménière's disease was examined bywaterloading, and antidiuresis was found in four patients. This antidiuresis seemed to be. caused by the dizziness attack produced by waterload, or by the labyrinthine stimuli to which. they were always exposed.

Mechanism of antidiuretic effect of the labyrinthine stimuli was discussed, and the author. suspected that it would be due to the incresse of the serum antidiuretic substances, and ink Ménière's disease, so-called "circulus vitiosus" was formed by the antidiuresis and the labyrinthinestimuli (dizziness attack).

\section{迷路刺激の抗利尿作用に関する実験的 並びに臨床的研究}

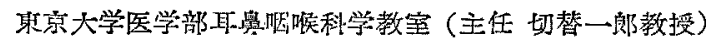

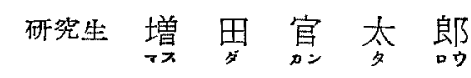

目次

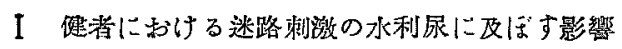

1. 緒言

2. 䒠験方法

3. 笑蹒成繢

4. 考案

5.小括

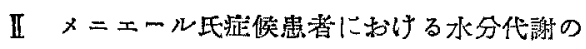

再検棓
1. 䋨言ならびに文献的考察
2. 検查船例の肉容
3. 实殹方法

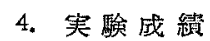
5. 唀案
6. 小 括
III 結 部
参桨支畧

\section{I健者に扣ける迷路刺激の水利尿に及ぼす影響}

\section{1. 緒言}

私達は迷路生理の矿究の一部として迷路と年梢循環と の関係を㭘討中，迷路刺激により腎容積か変動を示すこ
とを知りすでに報告したりの，乙の際当然利尿の変化子。 予想された。

近来運動・疼痛・外科的侵睡・電気ショック・感情緊 
張乞の他種々の刺激により利疗（以下特にことわらぬ限 り水利尿を指す）の抑制されることが明かにされてきた が，迷路刺激と水分代謝との関係についてはあまり䦭心 が持たれず従つて不明な点が多い，末田3) は家束に昼 夜連続で上下扣よび 傾斜動を与克尿量の漸減するを認 め, 前田 ${ }^{4)}$ は家鬼に長時間連続昇降運動を与之采尿を 認めた.人体でこれと閣連ある実験情航空医学方面で行 われているが5)6)，その目的上非常治い加速度を作朋 させるため遠心力るまた非常に大きく，循環系に対する 水万学的影響が強く出て，迷路生理学的にはほとんど参 考とならない。

私は人体で迷路刺激が抗利尿作用を有することを実験 的に証明し，その機序について若干の検討を加えたので こ〉報告する.

\section{2. 実験方法}

被検者：鼓膜正常で内耳機能・心・腎に 異常のない 健康青年男子を用いた，対照には他にメニェール氏症候 患者2名を用いた。

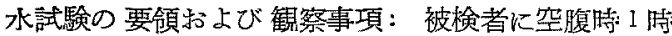
間以上の安静を保たせ 排尿後, 10 分以内に $1000 \mathrm{cc} の$ 水道水觉 领ませその後 10３0 分間隔で可及的完全に排 尿させ 4 時間にわたつてその利尿状況を観察した（例外

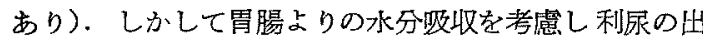
現を待って 主として飲水後 30〜60 分の間で迷路刺激を 加えた．被検者にはあらかじめ実験内容ならびにその無

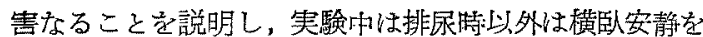
保たせて精神的あるいは体動による影響をできるだけ少 くするようにつとめた。

各分㽷につき气の量・比重を湘定し，また一部の例 でクレアチニン量を測定した。タレアチニンの定量は Folin 氏法の変法たる太田氏法7または Folin 氏法 によつた。

迷路刺激方法：A 群には往来の臨床的方法（迴転刺 激：10 6 迴転 $/ 20$ 秒, 外耳道よ りの温度刺激： $8 \sim 27^{\circ} \mathrm{C}$ 15〜40cc）のいずれか一方を 1〜数回加光た.

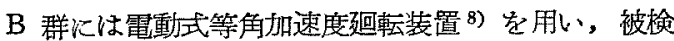
者をこの中心むるいはそれより $50 \mathrm{~cm}$ 離れた椅子に坐 らせ， $0.5 / \mathrm{sec}^{2}$ で加速迴転して $60 \% / \mathrm{sec}$ 等速迴転と乙， この状態で約 4 秒の週期で首（頭）を前後左右に振らせ た（図 1).経験によると前庭機能の正常な者ではかくす ること数分で乗物酥いの初期应状すなわち四胶冷感・冷 汗・顔面背白・悪心等が起つてくる．このようになつた ところで首振り突やめ $0.5 \% / \mathrm{sec}^{2}$ で減速し廻転を停止し
た。この場合作用する加速度はいわゆるコリォリ(Coliolis）の角速度であるが，その大きさは角加速度成分 $\pm 30^{\circ} / \mathrm{sec}^{2}$ ，直線加速度成分（遠心力） $\pm 0.06^{\circ} ， \mathrm{G}$ （重 刀加速度）であつていずれる生理的範国内にある.

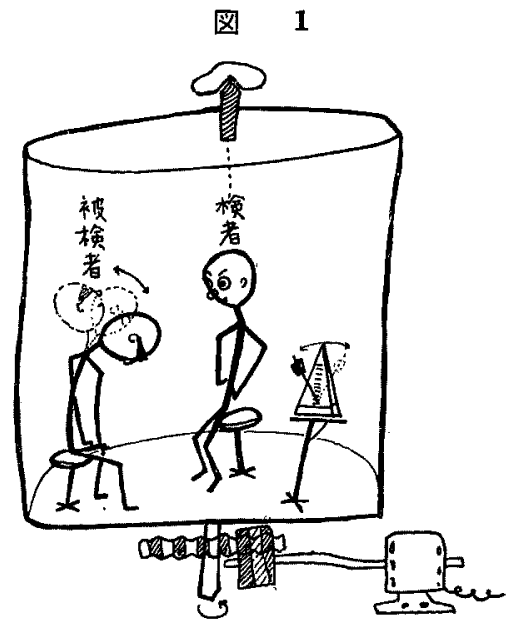

3. 実験成績

利尿および比重に及ぼす影饗

1） $\mathrm{A}$ 群（臨床的迷路刺激を加克たるの）

13 人につき計 17 回行つた. 表1にその大要をしめす。 結果はつぎの三通りに大別できる。

i）利尿に抑制的影響のなかつたるの：10 例

ii）著明な尿量減少は見られなからたが排尿量（cc/ 分）曲線掠上び尿量累計曲線から利尿抑制があつたもの と諗められ，かつ4 時間全尿量が $1000 \mathrm{cc}$ に達しなから たもの：4例.

iii）著明な一過性の利尿抑制が認められ，排尿曲線が 凹型を示したもの：3例・

対照ならびに ii)，iii）の数例を図に示す（図 2〜5). 刺激炕よる一般反応は種々であるが（表 1)，B 群炕 比して軽度でありまた利尿抑制と反灾の強さとの間に 法特にはつきりした関倸は認められなかつた。

な特 1 名のメニェール氏症候患者で臨床的迷路刺激饮 より利沓の抑制されたものが，ストレプトマイシン注射 (60g/30日) 後同様の刺激により眼振が現われなくなつ たときには利尿抑制もまた認められなかつた。

2）Ｂ群（迴転中首振りを行つたもの）

9 人につき計 20 回行つた（内 13 回は飲水前するいは 直後に硫酸アトロピン・クロールプロマジン・7\% 䨌曹 水・ドラマミン等を注射または内服により投与した。ド 
ラマミンを投与した2例空除いて）18例汇著明な利尿抑

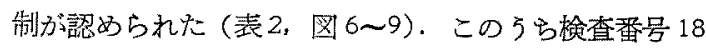
〜22, 25 は A 群の検㚗番号 10,11 と同一被検者で臨床 的迷路刺激では全く効果のなかったるのである。特纪领 水前後に 2 回刺激したものでは效果が潽明であつた（図

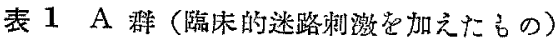

\begin{tabular}{|c|c|c|c|c|c|c|c|c|c|c|c|c|}
\hline 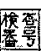 & & 年合制激方法要 & 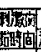 & 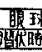 & 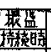 & 睡重 & 磨灾 & & (lack) & 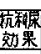 & 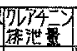 & 型 \\
\hline 1 & 1 & 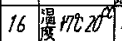 & $42^{\prime}$ & & & + & - & 351 & & $\frac{\pi}{n}$ & | & 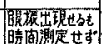 \\
\hline 2 & 2 & 23 晨12440 & $47^{\prime}$ & 0 & $765^{4}$ & Ht & - & 574 & & H & 㩲如 & 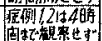 \\
\hline 3 & 3 & 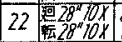 & $\begin{array}{l}355^{\prime} \\
50^{\prime}\end{array}$ & & $\begin{array}{l}60^{\circ} \\
54^{\circ}\end{array}$ & + & $\bar{z}$ & $381 \mid$ & 942 & \# & 減 少 & \\
\hline 4 & " & " & 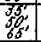 & & 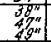 & 辛 & $\bar{E}$ & 1303 & 1475 & - & Far & \\
\hline 5 & 4 & $20 \quad 17020^{\circ}$ & $82^{\prime}$ & $14^{\prime \prime}$ & $115^{4}$ & + & + & 657 & 876 & + & $"$ & \\
\hline 6 & 5 & 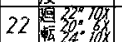 & 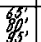 & & 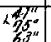 & + & $\bar{z}$ & 778 & 866 & + & 澌定世到 & \\
\hline 7 & 6 & 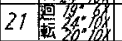 & 3, & & $20^{*}$ & \pm & $\bar{z}$ & 678 & 967 & + & " & \\
\hline 8 & 7 & 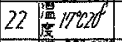 & $50^{\circ}$ & $7^{4}$ & $90^{\prime \prime}$ & \pm & - & 530 & 762 & + & 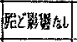 & \\
\hline$g$ & 8 & 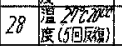 & $55^{\circ}$ & $25^{4}$ & $122^{\prime \prime}$ & + & - & 1000 & 1220 & - & $"$ & 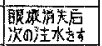 \\
\hline 10 & $"$ & $" 100.50$ & $30^{\prime}$ & & $140^{\circ}$ & + & - & 940 & 1285 & - & 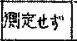 & \\
\hline 11 & $i$ & $"$ " $8^{\circ} 620^{n}$ & $-10^{\prime}$ & $15^{4}$ & $65^{\prime \prime}$ & + & - & $975 \mid$ & 1345 & - & $"$ & \\
\hline 12 & 9 & 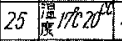 & $42^{\prime}$ & & $130^{4}$ & H & - & 986 & 1054 & - & 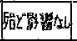 & \\
\hline 13 & 70 & $2015120^{\circ} 40^{\circ 0}$ & $47^{\prime}$ & 0. & $140^{\prime \prime}$ & 㖄 & - & 7042 & & - & $"$ & \\
\hline 14 & 11 & 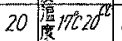 & $55^{\prime}$ & $10^{n}$ & $740^{\circ}$ & + & - & 817 & 967 & - & 戌定せず & \\
\hline 15 & 12 & 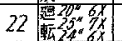 & 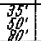 & & $3 z^{\prime \prime \prime}$ & + & - & 939 & & - & 增 加 & \\
\hline 16 & 13 & 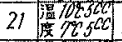 & 45 & $\begin{array}{l}15^{\prime \prime} \\
10^{\prime \prime} \\
\end{array}$ & $7175^{\circ}$ & \pm & $\overline{-}$ & 1474 & & - & 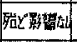 & \\
\hline 17 & $"$ & 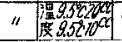 & 50 & 0 & $180^{\circ}$ & + & - & & & - & $"$ & \\
\hline
\end{tabular}

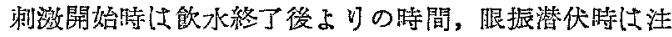

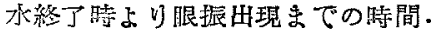

测砤方浩 溫度 $17^{\circ} \mathrm{C} 20 \mathrm{cc}$ 《 $17^{\circ} \mathrm{C}$ の冾水 $20 \mathrm{cc}$ 『 外耳道に注入. 迴転 $28 ” 10 \times \lll 28 ”$ 間に 10 迴転した

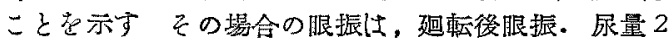
時間，4 時間は夫々飲水終了後 2 時間まで，4時間ま での尿量を示す。

図 2 対照

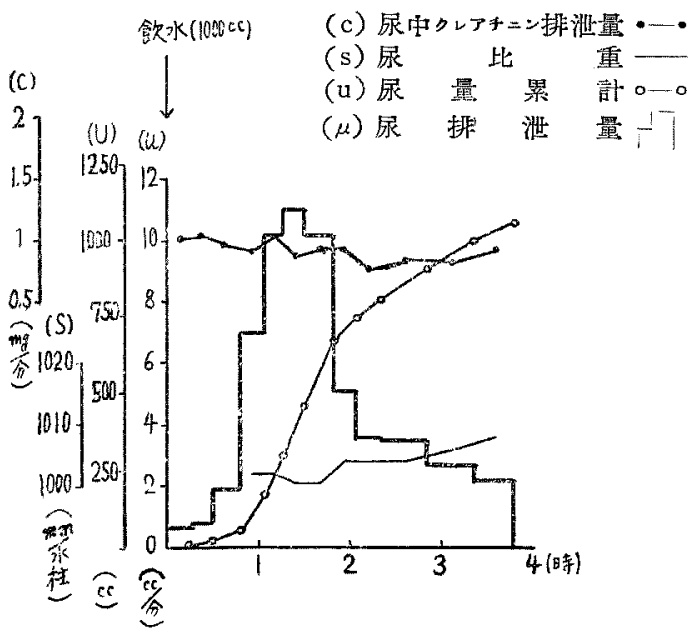

图 3 (検查番号 8)，A群。抗利尿效果 (十)の例

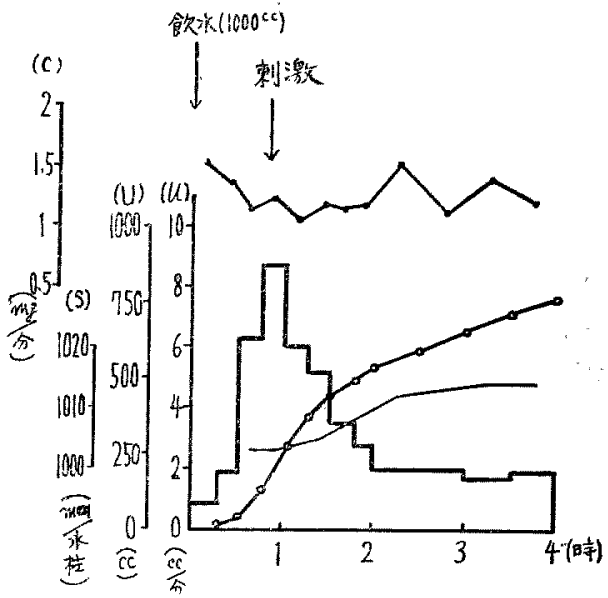

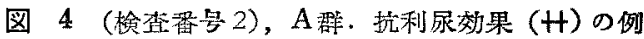

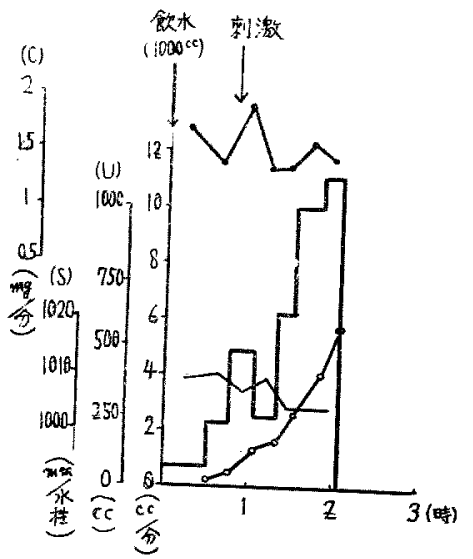

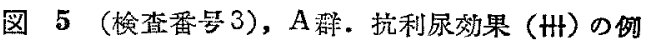
领水 $(1000 \mathrm{cc})$

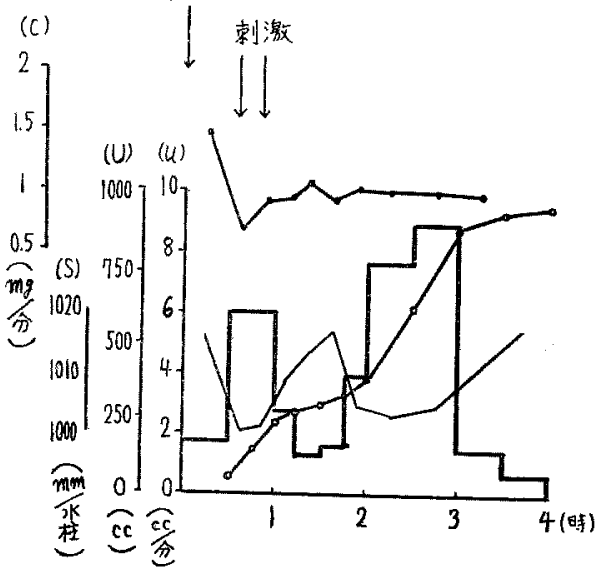


8).（な打迷路性抗利尿作用に及洔す蒋物の影響につい ては，あらためて発表する予定である。）

罒に見られるごとい B 群に括けるごとき典型的な抑

表 2 B 磻（趣転中首振りを行えるるの）

\begin{tabular}{|c|c|c|c|c|c|c|c|c|}
\hline 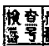 & & 整今年 & 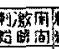 & 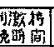 & 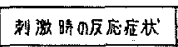 & 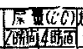 & 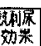 & 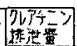 \\
\hline 18 & 8 & 31 & $54^{\prime}$ & 5 & 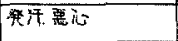 & 8981187 & H & 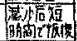 \\
\hline 19 & $"$ & " & $43^{\prime}$ & 7 & 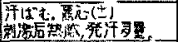 & \begin{tabular}{|l|l|}
228 & 765 \\
\end{tabular} & 卅 & F茠加? \\
\hline 20 & $"$ & " & $50^{\prime}$ & 5 & 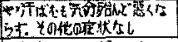 & 7839380 & \# & 激定世抹 \\
\hline 21 & 4 & " & $43^{\prime}$ & 3 & 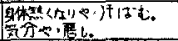 & 8021550 & int & \\
\hline 22 & $"$ & " & 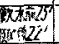 & $5_{1}^{\prime}$ & 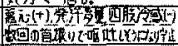 & 755628 & \# & 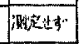 \\
\hline 23 & 14 & 27 & $55^{\prime}$ & 5 & 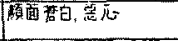 & 7851565 & Hif & 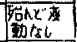 \\
\hline 24 & 15 & 30 & $29^{\prime}$ & $2.5^{\prime}$ & 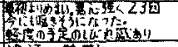 & \begin{tabular}{|l|l|}
152 & 984 \\
\end{tabular} & H & 政少 \\
\hline 25 & 8 & 31 & $33^{\prime}$ & $5^{\prime}$ & 证, 慜象 & 470 & Ht & 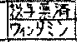 \\
\hline 26 & 16 & 21 & $5 f^{\prime \prime}$ & $2^{\prime}$ & 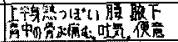 & 397 & 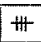 & $n$ \\
\hline 27 & 17 & 22 & $32^{\prime}$ & 5 & 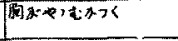 & $|1| \geqslant \mid$ & H & \\
\hline 28 & 78 & 22 & $49^{\prime}$ & 3 & 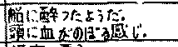 & 235 & \# & 0 \\
\hline 29 & 19 & 36 & $47^{\prime}$ & 5 & 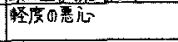 & 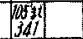 & H & $"$ \\
\hline 30 & " & $"$ & $64^{\prime}$ & 5 & 監元 & 259 & 类 & " \\
\hline 31 & 17 & 22 & $4 g^{\prime}$ & 4 & 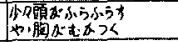 & 5048 & - & 1F5マシ \\
\hline 32 & 20 & 22 & $50^{\prime}$ & 3 & 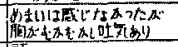 & 546 & \# & $n$ \\
\hline 33 & 21 & 23 & $54^{4}$ & ${ }^{\prime \prime}$ & 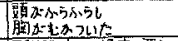 & 195 & $+H$ & \\
\hline 34 & 14 & 27 & $65^{\prime}$ & $5^{\prime}$ & 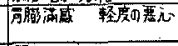 & 702 & - & $"$ \\
\hline 35 & 19 & 36 & $35^{\prime}$ & $5^{\prime}$ & 霓充 & 843 & \# & 侣ン \\
\hline 36 & 15 & 30 & $40^{\prime}$ & 2 & & 432 & H & " \\
\hline 37 & 14 & 27 & $40^{\prime}$ & $2^{\prime}$ & 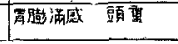 & $\mid \begin{array}{l}62542 \\
6222\end{array}$ & + & $"$ \\
\hline
\end{tabular}

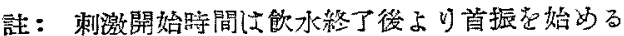
までの等間.

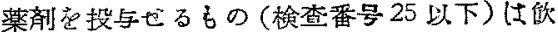
水終了後約 2 垁間まで覞察。

図 7 (梌查番号 21)，B粼

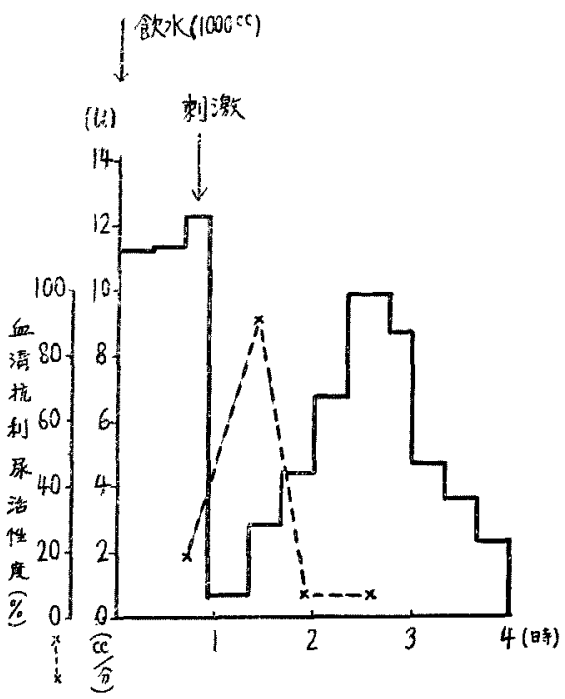

制を示す場合には約 10 分以内の 潜伏期のつち 尿量は短 洼澗内に急激に減少して活とえぞ最低値まで澾し一定の 持続時間後比較的徐々に堌加し約 90〜120 分で全く恢得

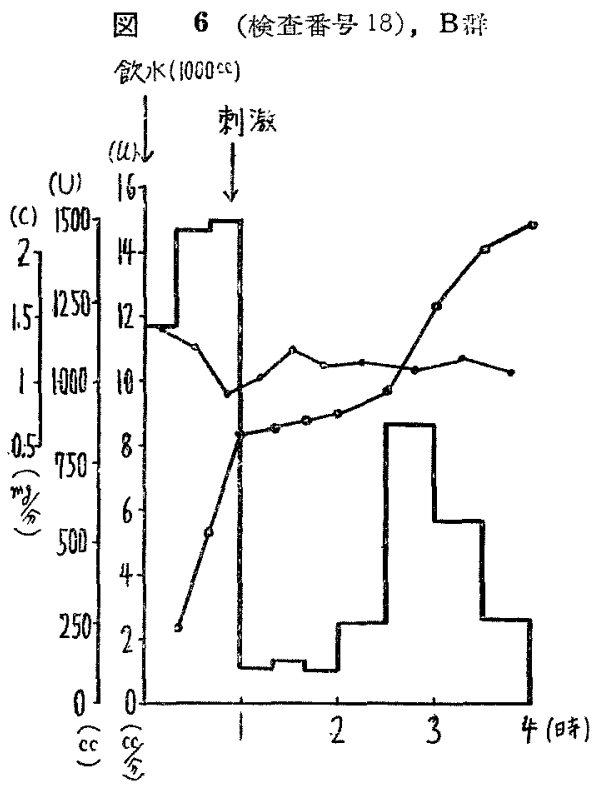

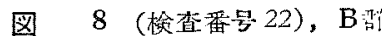
㪘水 $\left(1000^{\mathrm{cc}}\right)$

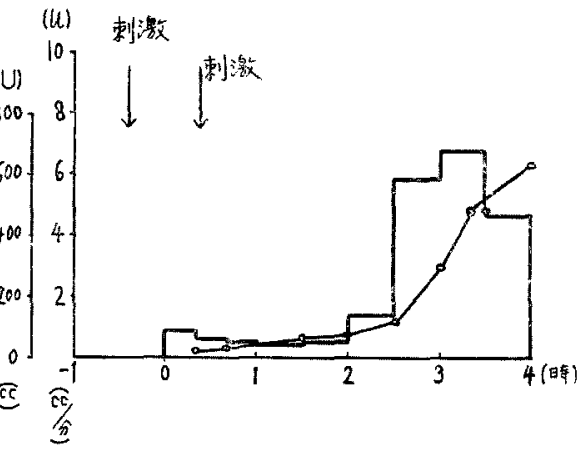




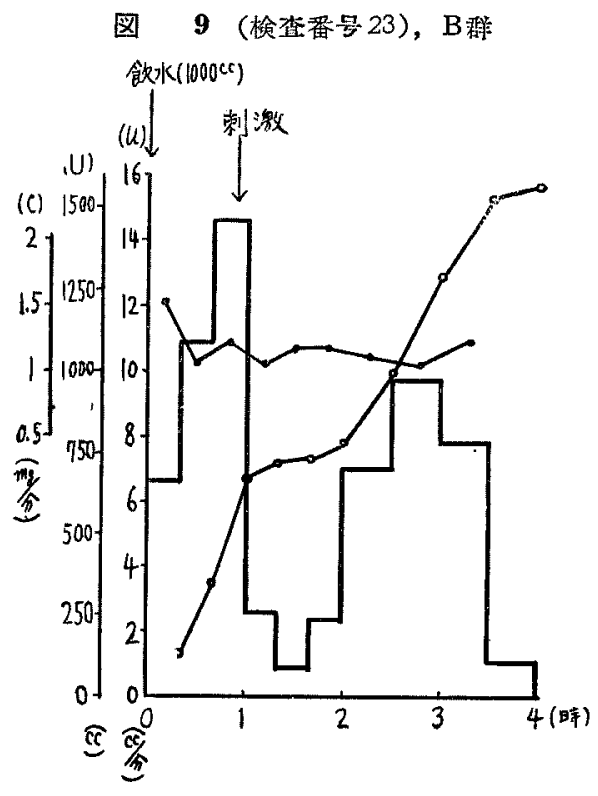

图 10 対照, B活

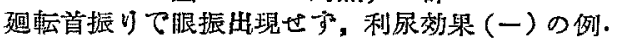

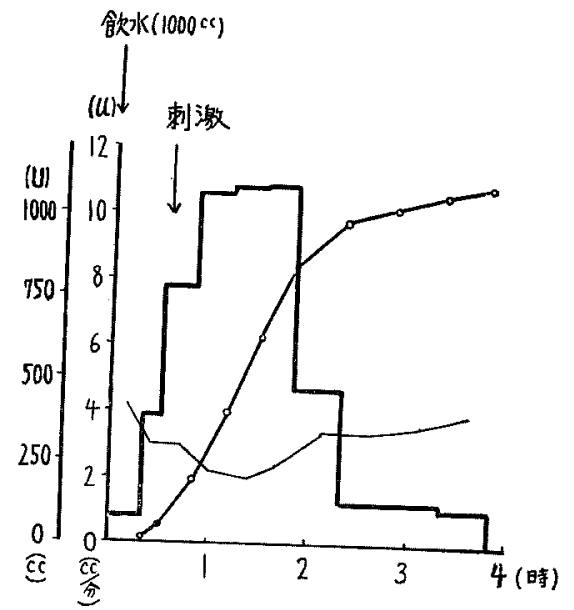

する。この間比重は尿量と逆の経過をたどり，尿色調も 同様である・（上記特間の值は排泉間隔が長いこと，お よび束激後第 1 回目の分疛が束激前扣よび刺激中の尿も 含むたみ正砤とはい壳ない)

対昭として, 迷路機能が強く侵され，廻転中首振りに より眩最を感じなかったメンェール氏患者では抑制が認 められなかつた（図 10).また偆者で迴転は行わず首振 りのみ 5 分間行つたもの，迴転空で首振りは行わず迴転 のみ 5 分間行つたものではいずれも抑制は認められなか つた.
A 群，B 群狺よびそれらの対绍実䟻を通じて比重は 常に尿量と逆の経過を示した。

クレアチーン排淮量に及ばす影留》

水試験のみの場合および刺邀により抗利尿効果のない 場合には「タ」排泄量には注とえど变動がなかったたた だし领长後第 1 回目の分尿に括ける「タ」排海量は非常 に高い傎を余す它のるあつたが，これは試験前膀胱洗涤 を行わなかつたので, 领水前の晴厚な尿が完全には排除 されないための影響と思市れる。

利尿が抑制された場合には「ク」排泄量はほとえど卒 動しない場合，増加する増合，減少する場合等複雑であ つて一定の傾向は見られなかつた. そしてその変動:尿 量の変動と必ずしも並行せず尿量の減少している部分で 「夕」排泄量の 増加している例や，剌激後一且低下を示 すが尿量減少特にはすでに元に杘つている例などがあ る.一般に「ク」排泄量の变㗢は尿量の变動よりる洔間 的に短い経過を示した。すなわち尿量の減少と「ク」の 変動とは互に独さ江した現象である。

\section{4. 考按}

以上の実験から臨床的迷路刺激および廻転中首振り刺 激が尿濃縮をともなら抗利尿作用を有することかかかつ た。

この埸合利尿抑制をきたす機序として迷路束激以外に 問題となるのは次の 2 つである.

1）廻転の場合，遠心力による一般循環系ひいては腎 血流に及ぼすフ水力学的影䈉,

2）温刺激の場合，外耳道皮蜀を介しての寒冷反射. 遠心打の心に対する身体遠隔部に血液の偏在が起る 程度の大きな遠心才を作用させた湯合には脳の動脈圧低 下・酸素欠乏をきたし腎䩱入細動脈の彼縮の結果，ある い值接篮への血流の減少见よつて糸球体濾過值 (G.F. R.) の低下ナることが考光られるデ，私の垁験の場合汇 は遠心力が小さいのでそのようなことは考えられない。 Stauffer 5) 6) 等はそのよ5な大きな $(3 \mathrm{G} \sim 5 \mathrm{G})$ 遠心力 を作用せしめ（ただし頭は動かさない）利尿抑制を㒛め たがその効果はほぼ 35 分で恢復しはじめ60 分で元の值 の半分まで恢復している(60 分までしか観察してないた めその後の経過は不明であるが，尿量のカーブを延長し て予想すると 90 分前後で元の值に復すると思われる). 給水条件がことなるため精朚な比較はできないがその抗 利尿効果の程度は私の或喝の場合より小さいと思われ

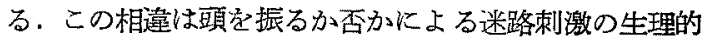
な強さの差によるものであろう・自覚的にも頭を振ると 
否とでは眩最の程度が非常にことなるが，動摇病の生起 飞は頭の動きが重要な関係を有することが知られてい $る^{111}$.

次に臨床的迷路刺激の备転の方が趣転社を用いた B 群の場合よりも停止洔:の迴鞋加速度が大であるにか力わ らず抗利尿效果の大きさはむしろ逆であつた。

また B 群では迷路機能正常者では例外なく著明な利 尿泖制が勰められたぶ，迷路機能低下せる1例では全く 認められなかつた（四10).

これらのことより(1）の水方学的影響恃無視してよい と考える。

次に外耳道冷刺激の場合の寒冷反射の影響を云々する には外耳道皮虞の (寒冷) 知賞麻瘦者か, 迷路機往廃絶 者の多くについて実験しなければならないか，このよう なことは人体では困難である・ただメニエール氏症候患 者の 1 例で，冷刺激に上り利尿抑制の認められた子の が、ストレプトマイシン投与による迷路機能低下後には 同様の刺激で認められなくなつたので寒冷反射の影㗽む 閣題にならぬ程度のものと思われる。をた抗利尿効果は

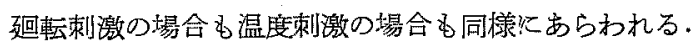

以上の諸点から本実験で見られた抗利尿効果は主とし て䢞路刺激汇よるものと見做して差支劣ないと考える。

さて蹺床的迷路刺激では 17 例中 7 例儿，廹転中首振 りでは20 例中ドラマミン定投与せる2例赏䟻いて 全部

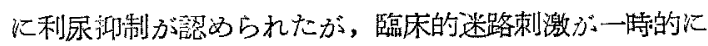
強い胘最をきたしても全身的反応は比較的少心(悪心を 起したものはほとんどない）のに付し，迴転中首振りで は一過性にせよ例外なく乘物酥、の症状を呈した。従つ て乗物酔いの症状起す程度まで刺激を強くすれば例外 なく利尿抑制が起るものと若えられる。

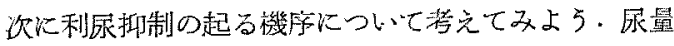
る最終的左右する因子小 G.F.R. (米球体濾過值) 腎細尿管上りの水分再吸収である。すなかち 1) 血管運 動神経杂介しての篎血管に対する影響から G.F.R.の低

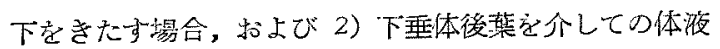
性あるいは水ルモン（抗利尿ホルモン）性の抑制である。

内因性クレアチニンの排泄量 $(\mathrm{mg} /$ 分) の增減性近似

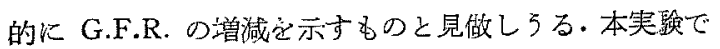
は利尿の㧕制された場合に「夕」排泄量は增減一定せすき その経過も利尿抑制儿比し短い傾向がある。従つて一部 は G.F.R. の低下に上る影響も考光られるが本質的には これで䗑明することは困難である・閃北刺激 ${ }^{11}$, Pitres$\sin { }^{12)}$ 注射炕よる利尿抑制の場合にも尿量と G.F.R. が
逆の経過を示すという。

次に本䇛験に括ける利尿抑制が水分再败収の增加に上 るものとすれば利尿抑制の㭙阴に一致して血清の抗利尿 活性底 ${ }^{13)}$ がたかまつているはずである.そこで B 群 の数例について 同持に大園のう法 13) に上りこれを測定 した（測定は東大本本外科市川学士に依頼）ラッテの 状態が良好でなく失敗した例るあつたが，ラッテの状態 良好で信頼し得ると考えられる例では利尿抑制特汇抗利 尿活性度が高かつた（図 7).すなわちこの㭙期において 血清中の抗利尿物質—恐らく抗利尿ホルモン一が曾 加していることがれかる.

な招水と Pituitrin を同時に与えると不感蒸泄がた

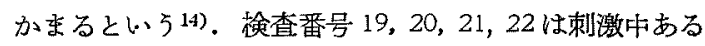
いは刺激直後短侍間の発汗が認められたが，発汗の消失 後も抑制は長く続き，発汗の認められぬ例でも同様汇顯 著な利尿抑制が認められているので，発汗・不感蒸䀝の 昂進があつたとしても、これのみによつてこの強い利尿 抑制を説明することはできないであるう。さしろ発汗・ 不感蒸泄昂進は利尿抑制と同時江起る現象あるいは利尿 抑制の代償的見象之考える万が抑制の強さから考学て妥 当の上うに思われる。

これ要するに迷路性の抗利尿作用は G.F.R. の低下 あるい性発汗・不感蒸泄の增加等警外性の要因の影響を 受ける場合もありらるが，本質的には血清中抗利尿物䐝 の增加による水分再吸収の堌進によるものと考えられ る.

\section{5. 小 括}

1. 健康青年男子に $1000 \mathrm{cc}$ の水を負荷したのら迷路 刺激を加えて，迷路刺激の利尿に及洔す影響离観察し た。

2. 臨床的迷路刺激 (迴転刺激, 外耳道上りの冷刺激) では 13 人に 17 回行つて7 回に, また迴転室にて迴転し

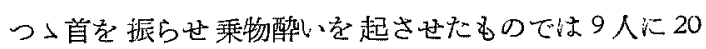
回行つてドラマミンを投与せる2例を除いて18 回に,

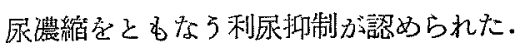

3. 㴹路機能の泟と几ど廃絶し実験的迷路刺激により 眩暴・眼振の起らなかつたメニェール氏应候患者2名で は利尿抑制も認められなかつた。

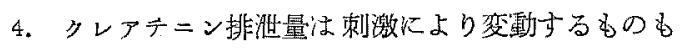
あつたが一定の傾问はみられなかつた。

5. 迷路性挖利尿作用の機京について考察し, 主とし て血清中抗利㲾物質増加による水分再吸収の橧進による るのであろらと推論した。 


\section{IX メニエール氏症候患者に持ける水分代謝の再検討}

\section{1. 緒言ならびに文献的考察}

Hallpike ${ }^{15)}$, Rollin ${ }^{16)}$, 山川 ${ }^{17)}$ 等の報告以来 $x==$ 一几民症掭（以下*氏症侯と略す）の病理解剖が朋が なるにつれて， ×氏症候の本態として内ッンバ水堙 ${ }^{15}$

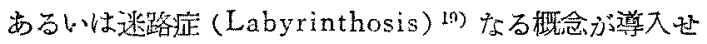
られ，その成因の一つとして全身あるいは同所の水分代 謝異常少落えられるようになつた。

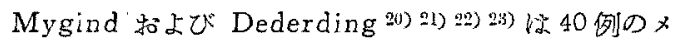

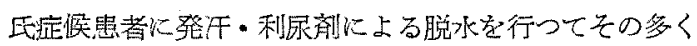

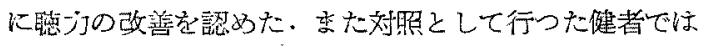
代儥性乏㞗が起つたがメ氏症候患者ではそのようなこと がなかつた、これらのことからメ氏应候患者には前的つ

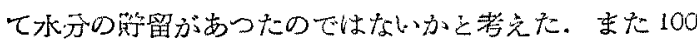
例の患者に水分顀荷 $(10 \mathrm{COCc})$ 試駼を行いその半数以上

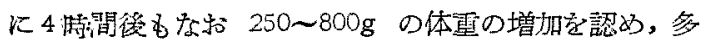
数に聴う減退あるい怯頭重・頭痛・耳鳴の堌强の起るこ と变锶察した。しかしてそれらはへマトクリット值から 予想される血清稀橎度の経過とよく一致した．䇏照の耳 硬化症の患者にはかっる聴力減退が認められなかつたこ

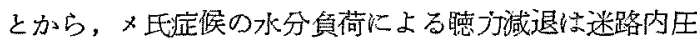
の穴進にもとずく鐙骨の可勒性の低下によるるのであ り，x氏症侯の基本的要因は全身または局所の水分貯溜 傾向てめると結䜽した. Nielsen の説:蕒成している。

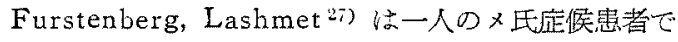

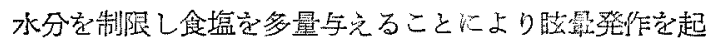

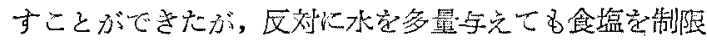
すれば登作の起らながったこえから，登作の発生いかん

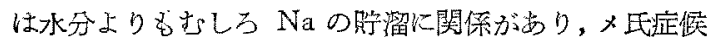

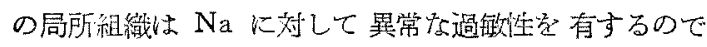

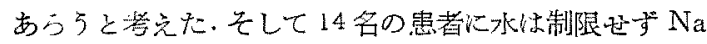

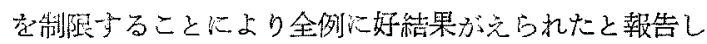
ている. Brown 28) 屯同樣の結梁をえたとい5。

Mygind 北よび Dederding はこれに対し眩最発作 次证状の覀化するときばかりてなく改善されるともも起 ることがあるので, 治療都果の判定恃聴力の改善いかん を指標とすバきであるのた Furstenberg 等俚全く聴斿 の变化を見ていないこと，亦た大量の食䘏索与えた場合

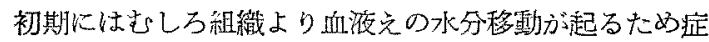
状が一海的に改善さ机る点埌指摘し Furstenberg 等の

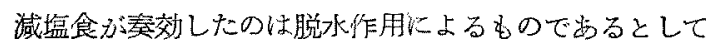
长分貯溜がやはり第一義的臂因であると反跤した。

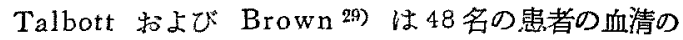
水分・䍿白質量・Na・K 执よび全結合熄基を詳細に定 量した結楽，水分あるいは $\mathrm{Na}$ の眝溜方×氏应候の要 因と考克られるような結論は壳られなかつた・そして発 作中の患省の血清に K 濃度が特に高かつた事奏から減 塭食の有効なのは $\mathrm{Na}$ の絶対量によるものではなく， $\mathrm{K}$ : Na の比の変化によるのではないかる者えた。 そこ で $\mathrm{Na}$ は制限せす $\mathrm{K}$ 過㖶に与えてみたところ皆有效 であつた。彼は Kイホンの利尿作用がこの場合重要な 急味を有することを認かつ〉も，それのみでは説明でき Qとして 2,3 の推論弆述べている.

Perlmann, Goldinger 㣘よび Cales ${ }^{30}$ は 15 名の

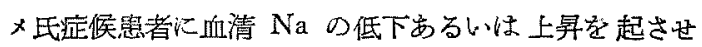
てその影響を調べたが，一定の結果がえられなかつた。

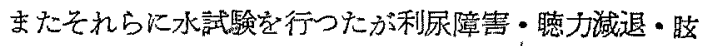
需発作氺全く認められなかつたという

また最近山田等引1は副督皮質機能の方面からこの問 題を取上げているのが注目される。

以上メ氏症候と水分あるいは電解質代謝问関する往来 の策蹟の穊要を述べたが，水分代謝定重視するるの， $\mathrm{Na}$

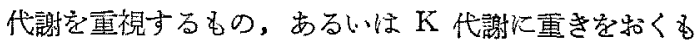

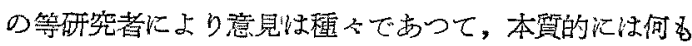
わかつていないのが現状である。彷来の研究索検討して

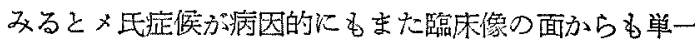
な疾甞でないのにかつわらず総括的に取扱つているとこ

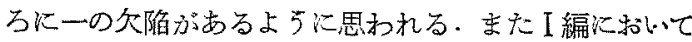
迷路刺激が利尿学抑制子るここを知つたが，×氏症候患

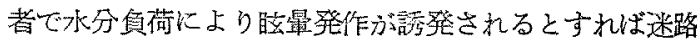

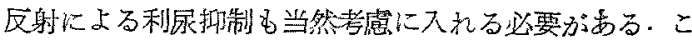
れらの観点から私、各症例について詳しく检詩し、いか なる症例でいがる状態のときに水分代謝異常がみられ るふを調べ，その機序壳考察した。

\section{2. 検查症例の内容}

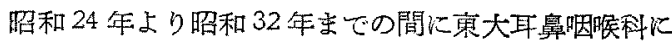
入院した原因不明の×氏症候患者の5方水試駼（水分負

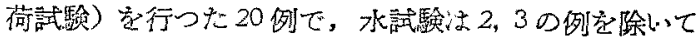
は特に症例を選んで行つたものではなく入院装:の㭘查の 一部として行つたものである。症例はいずれる㹂・山疾 虫なく梅毒血清反応は阷性である，各症例の要約を溒 1 に示したが表中記载事項法入院斿所見を元とした。

これらを渡辺 ${ }^{32)}$ の臨床的分類法によつて分類すると 埊 2 のとく雑型をのぞいてはすべての型が含まれてい 


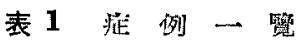

\begin{tabular}{|c|c|c|c|c|c|c|c|c|c|}
\hline 症例 & $\begin{array}{l}\text { 塈 } \\
\text { 症 }\end{array}$ & $\begin{array}{l}\text { 主 } \\
\text { 許 }\end{array}$ & 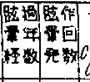 & 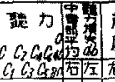 & 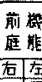 & 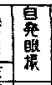 & & & 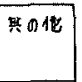 \\
\hline 519 & & 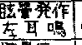 & 8 日10*2: & 5.7 & 焉正 & $(-1)$ & & 䨝 & \\
\hline 23218 & & 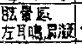 & 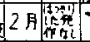 & 2217 & $" 1$ & $(-)$ & & . & \\
\hline & & & 8 年1 & 323 & $\Rightarrow "$ & $(-)$ & $(-)$ & 䟦 & \\
\hline 4396 & & 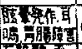 & 6月願國 & 57 & $.1 \frac{6}{7}$ & {$[(-)$} & $(+)$ & (fin: & $\sqrt{\beta_{2}}$ \\
\hline 53218 & & 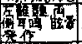 & 271006 & 527 & $\cdot 1$. & 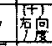 & $(+)$ & I & \\
\hline $6 \mid 3818$ & & & 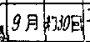 & 253 & 4 & (-) & $(+)$ & 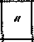 & \\
\hline & & 魰 & 4月頭回 & ii $22|2|$ & $"$ & tit & & $"$ & \\
\hline & & 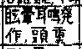 & $\begin{array}{lll}3 \text { 7 } & 6 \text { 回 } \\
\end{array}$ & 82032 & $\frac{100}{F}$ & E & $(t)$ & " & \\
\hline & & $\frac{6}{3}$ & 2湑/回 & 07 & & $(-y$ & $(+)$ & $"$ & \\
\hline tot & & 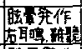 & 3 年2000 & 3926 & 焉 & $\frac{\sqrt{5}}{2} \frac{1+1}{7}$ & $(+1$ & 4 & \\
\hline $1 / 162$ & 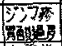 & 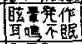 & $2.5 \mid 006$ & 3212 & ". & $4 \frac{10}{5}$ & $(+)$ & $"$ & \\
\hline $1219 \mid \hat{b}$ & & 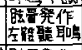 & 36 年 6 回 & 0132 & 佌 & $\frac{1}{T}(-)$ & & II & \\
\hline & 15y & 睛奇觉作 & 4月17日 & $\Longrightarrow .20152$ & 正 & $\begin{array}{c}\frac{5}{5} \\
\frac{5}{2}\end{array}$ & $(t)$ & $"$ & \\
\hline 4239 & $\left\{\begin{array}{l}4 \\
5\end{array}\right.$ & 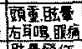 & 3460 & $\because 379$ & " & $" 1-1$ & $(i+)$ & $"$ & 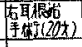 \\
\hline & & & 10 月 & 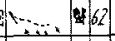 & 佂 & \begin{tabular}{l|l}
$\| 1+3$ \\
\end{tabular} & ) $(+)$ & $"$ & \\
\hline 16546 & 8 & & 378 年 & $\ldots-1284$ & $"$ & $4(-1)$ & $(-)$ & $" \prime$ & 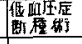 \\
\hline 20 & $x_{-107}$ & 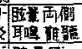 & 3 年部国 & 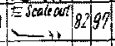 & $\sqrt{\frac{E}{2}}$ & " & (a) & $"$ & \\
\hline & 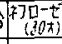 & 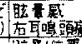 & 5 年100 & -10 39 & & 集 $(-)$ & $(++)$ & $"$ & \\
\hline & & 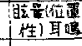 & 17 日用 & +497 & I. & 焉(1-) & $1+1$ & 证 & \\
\hline 202518 & & & 4 月 1 回 & $\therefore 18.52$ & & $(-)$ & & 4 & \\
\hline
\end{tabular}

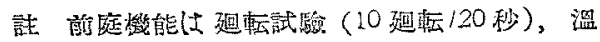
度試驗 $\left(27^{\circ} 20 \mathrm{cc}\right)$ の結望に゙より制定した。

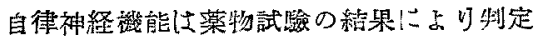
した。

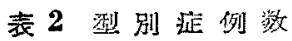

\begin{tabular}{|c|c|c|c|c|c|c|}
\hline 型 & 不完全型 & 俥琹症型 & $\begin{array}{l}\text { 迵期的 } \\
\text { 攴復型 } \\
\text { (I型) }\end{array}$ & $\begin{array}{l}\text { 不䂓則 } \\
\text { 重症型 } \\
\text { (II型) }\end{array}$ & 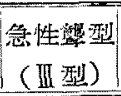 & 棓 \\
\hline 例数 & 2 & 2 & 7 & 7 & 2 & 20 \\
\hline
\end{tabular}

る・こっでこれらの型とついて簡巣代説明を加光る。

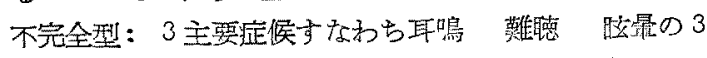
つがそろつていないもので、い和る作性メ氏病もこれ に含まれ，呟暈は一般渾度である。

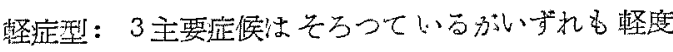
で中音部平均聴才損失 $40 \mathrm{db}$ 以内で，はつきりした卒中

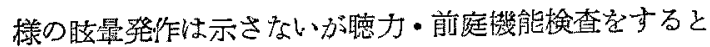

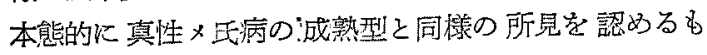
の.

週其腺反覆型（I 型）：いわわる興型的メ氏病に相当 乙賠最発作を週期的汇起すがその発作は可逆性一長く む半月位の比较的短期間に少くとも自覚的には発”作前と 同様な状態にもどるもの一であらて，中音部平均䏯力 損失 $40 \mathrm{db}$ 以内 (非発作㭙) のもの.
不規則重症型（II 型）：軽症型に対するもので萪聴が中 音部平均聴力損失 $40 \mathrm{db}$ 以上飞達したもの，あるい性藉 嗃はそれほど高度でなくても矓最が不規則な起り方を し，しかも高度で発作中性起きていられぬるの。

この中には I 型の末期や間歇期のものが含まれると同 䏯に中耳炎や外賃に上る二次的な迷路病变でその性質が 内リンパ水腫やラビリントージスに相当すると考党られ るものや中枢性病変も含むと考允られ，その症例の樹成 はかなり複維である万と考劣られる。

急性難德型：いがる Sudden deafness の型で起 つたメ氏症候卒中型で岕る。一回の発作で患者は汪とん ど“ろう”となり恢復不良であるが䏠聂発作の再発依ま れである。

以上の諸型を胉舅あるい汒迷路の刺激状態の面からみ ると藷者の検查した症例では不完全型・軽症型和よび I 型は一般に非発作㭙火は矓昱なく迷路の異常刺激状態か ら一応解放されていると洘克られるものが多いのに反し

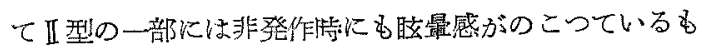
の汸あり，か子る例ては迷路は常に異常状態にあると考 觉られる、正型は発作の再発はまれなので，ある一定期 間が過ぎれば一般に異常迷路刺激状態からは開放され る.

\section{3. 寄験方法}

上記患者で脑晕発作のない時期に，空腹畤（主として

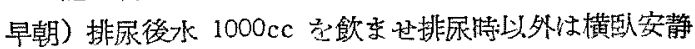
を保たせ4時閒にわたつて次の事柄を観察した。試験前 後の体重, 毎30 分尿量, 之の比重, 眩显発作・眼振・ 耳鳴・難聴・悪心・塸吐等の症状の誘発乃至堌強の有無

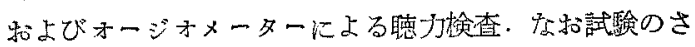
いには室温に注意し温度による影饗をできるだけ避ける よう心掛けた。また排尿幄延の判定は金井の臨床検査法 33） 儿準趐して

1）飲水後 4 特盟以内以その大部分（900〜1000cc）を 排出しないもの

2）最大 30 分尿の発来が初めの 2 持間上り遅れるか，

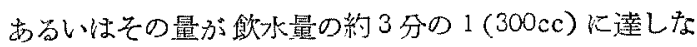
いわの

以上の項目のいず机かるるい性両者に該当するすのを 排㽷遅延（+）とした。

\section{4. 実歌成精}

大要を表 3 に示した放要約すると次のごとくである。 眼振・䏠聂をきたしたものが5例。

眼振・眩最はないが耳鳴増強・悪心等の症状を起したも 
表 3 水試瞼成䌉

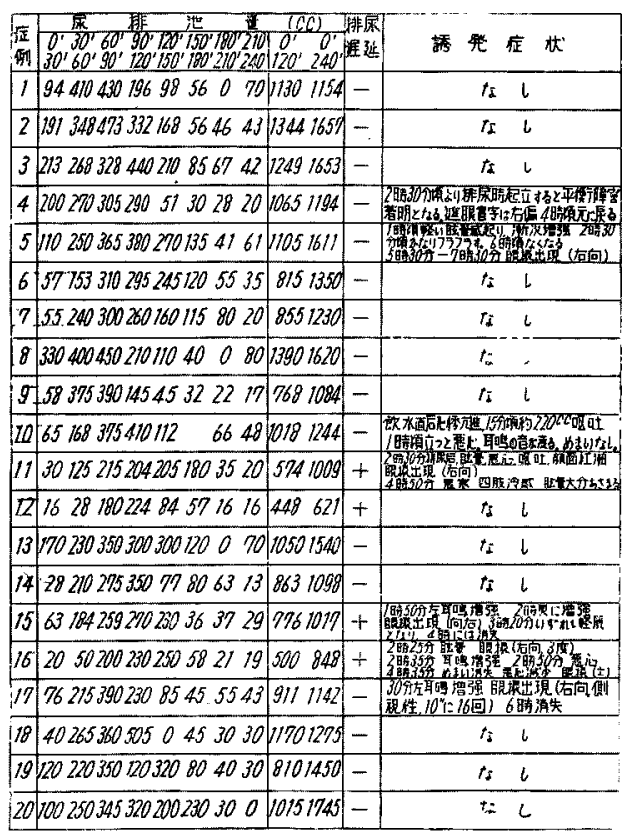

のが 2 例.

排尿遅延山る8のが4例.

試験中聴力検查を行つた日のは症例 2,7,10,17,18の 5 例であるが,変動を示したるのと示さぬるのがあつた。

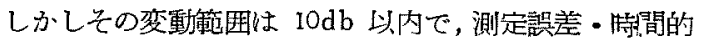

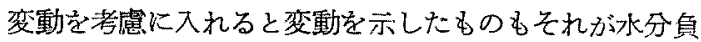
荷によると見做すことは他険である。

体重の増加を示したものは一例もなく皆娍少を示し t丷.

次に主なる症例について説明する。それらの主訴・前 庭譏能・聴力等は表 1 を参照されたい。

症例 No.5.32 才. 8 (I 型)，昭和 31.4 .26 入院.

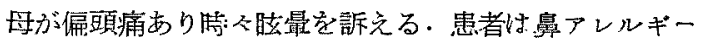
があり莧物㭘查により自律神経不安定 $(+)$.

炤和 28 年 5 月頃より洞耳閉寒感 (ガーンとした感じ, 耳鳴?），左難聴あり通気・鼓膜マッサージ無效、

29 年8月より陆々フラフラなる。.

31 年 2 月中旬よりそれがや〉強くなり同年3月1日就裳 中強い瞈量発作が初めて起つた。矓最はつかまり步きが できる程度. 覀心・嘔吐ありしばらく横卧して执さまつ た. その後同㨾の発作方週 2 回位の割に週期的に起り 2 時間位で恢復する・非発作㭙には耳鳴・難聴があるだけ である。
水試験（図 1）の利尿状況は正常あるいはむしろ過榃 であるが矓暴発作が発来した。すなおち飲水後約 I時間 で軽い胘最感（乘物に酔つたような感じ）が起り徐々に 強くなつて 2 時 30 分頃にはかなりフラフラし，以後同 じ状態が 5 時 30 頃まで続き6時頃なくなつた。 5 特 30 分頃上り 7 分㥧登で右に向５水平性迴転性の自発 眼振が認められた。

图 1 藏例 5

発作誘発 $(+)$ ，排尿逮莚 $(-)$ の列

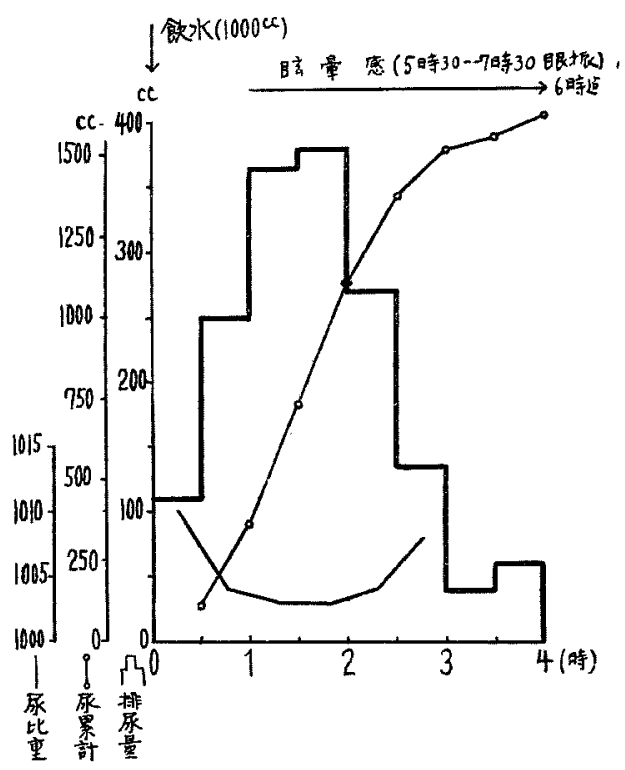

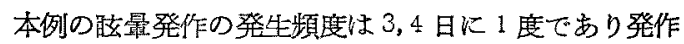
のあつた次の日に水試験を行つたので試験的の発作は水 分負荷によつて誘発された6のと考えられら。

症例 No.11.62才，才（I 型), 昭和 27.12.18 入院.

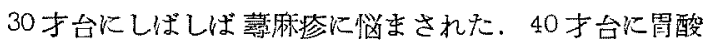

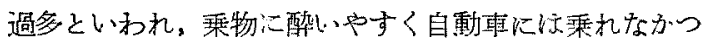
た。

䀡和 25 年 6 月上り不眠, 特定D食物（标・林・肉等） の摄取驾誘因として，峁るいは誘因と思われることなく 照最発作ぶ同 27 年 10 月までに5回起つた。27年 11 月

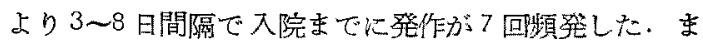

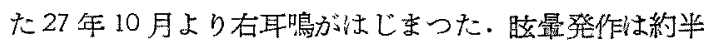

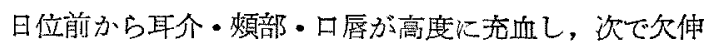

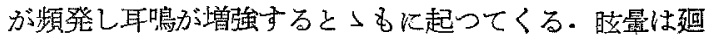
転性で悪心・嘔吐・頭重・熱感・耳閔寒感・然骨神経痛 ・重液分速増加・発汗をともなう。 
水訊驗 (図 2) の利尿状況は最初の 2 㭙間排尿量召 574 cc で少く，最大 30 分尿が $300 \mathrm{cc}$ に達せずから 2 時間 以後にきていることから明が排尿遅延の傾向がある. また 2 時: 30 分頃顔面紅潮と〉む睹最・右に向 5 水平

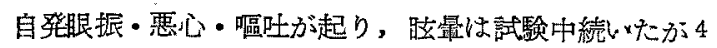
时: 5 分にテブロン $200 \mathrm{mg}$ 注射し，4時 45 分頃には顔面 の紅潮がとれ，要寒・四肢冷感を訴え，眩最もほとんぞ 招さまつた。

\section{图 2 篮 例 11}

発作誘発 $(+)$ ，排尿逮延 $(+)$ の例

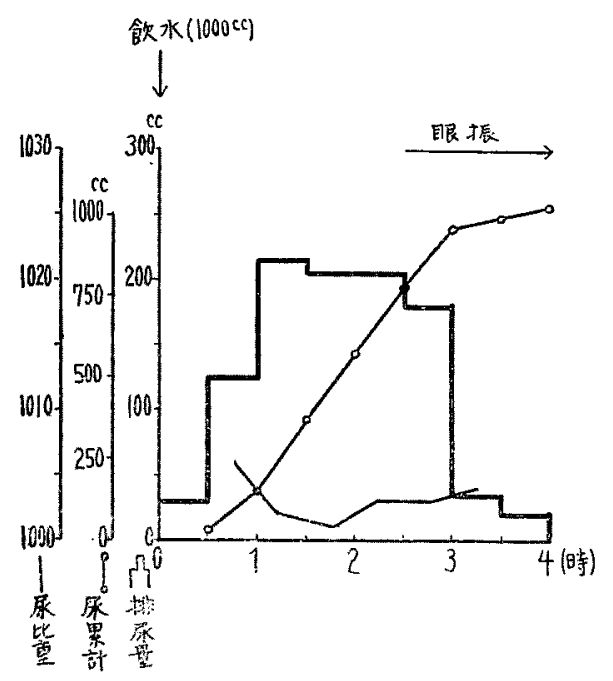

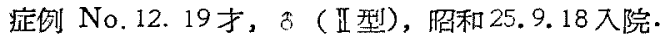
母方の祖父母脳出血. 父主勫脈硬化症, 一側眼底出血 のため視力障碍あり．兄住幼時より四肢運動障害があ る。

嚾和 23.6.25. 夕刻突然迴転性胘最・悪心・嘔吐をき

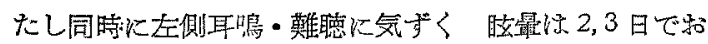
さまつたが耳鳴・難腹はとれず，同年 7 月通気を受けた が無效. その後同様の発作が 10 日〜4ケ月位の間榢で 5 回起つている.

水試験は 2 回行つたがいずれも 4 時間全排㞗量が 621

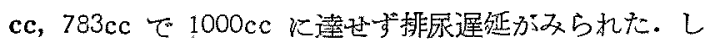
かし体重は $2.85 \mathrm{~kg}, 0.2 \mathrm{~kg}$ ずつ減少している.また矓最 その他の症状の誘発恃認められなかつた（図３），念のた

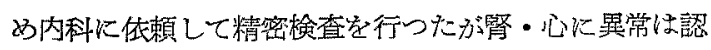
められなかつた。

症例 No.15.44 寸，方（II型）, 昭和 27.4.1 入院. 昭和 25 年 11 月右側難聴・耳鳴に気す昭和 26 年 3 月
图 3 症 例 12

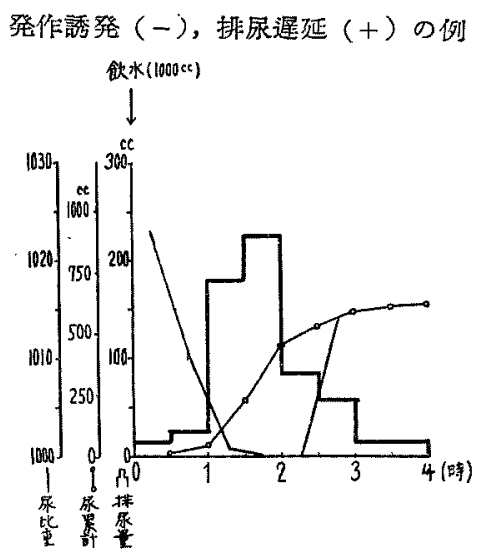

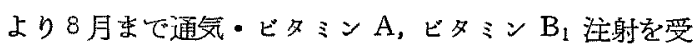
けたが無効・

昭和 28 年 2 月左耳閉寒感仅気付き通気を受けたが無 効・同年 4 月東大耳鼻科を訪れた。 6 月までビタミン $\mathrm{B}_{1}$ $40 \mathrm{mg}$ 静注 20 回, エナルモン $8 \mathrm{mg}, 7 \%$ 重曹注射 10 回 等を受けたが效なく左耳鳴るはじをる。6月末より郝ね

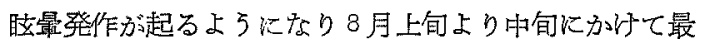
もはげしく陮床できず

水試験成績は症例 11 と似て呫り最大半持間尿が 300

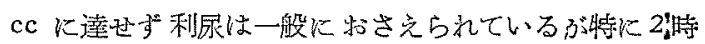
間頃より眼振岕らわれてのら急に尿量が減少している のが目江つ. 耳鳴堌強子㒛好られた (図4).

图 4 证 例 15

発作誘発 $(+)$, 排尿漣延 $(+)$ の例

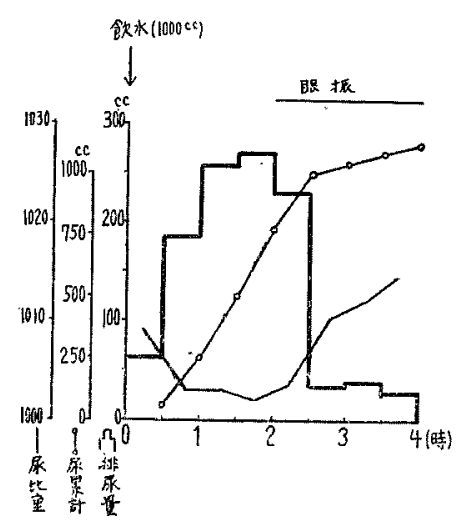

症例 No.16.54 才, 合 (II型), 路和 24.5.30 入院. 15 才時左中耳炎， 35 才時画側実質性角膜炎に羅患，乙 かし 血清梅毒反応陰性・砲兵生活 30 年でしばしば爆発 
音沉接す

昭和 4 年頃約 1 ケ月間眩最のあつたことがある.昭和 22 年右難聴・耳鳴はじまり同年 10 月初旬迴転性胘暴発 作就こり，悪心・嘔吐をともない３0 分位で眩最は とれたが，身体動摇感忹1週間続いた。 以後 11 月 半ばをでに 3 回同様の 発作が あつた。昭和 23 年 3 月から時及身体の重心がうしなわれるようでよろめ き某内科医の投薬を受けていたが溸次增強し7月よ り 2 ケ月間就床した，灻の後大分軽快したが動摇感 はとれなかつた。

昭和 24 年 1 月よりふたつび脑最强くなり某医に ピロカルピン療法觉受けたがが完つて增悪し7月， 11 月に強い発作があった。12月東大耳鼻科を訪れ 炤和 25 年 4 月入院した。

患者年平素汗かきで汗をかいたすとは調子がよく，な た発作後大量の排㲾のあることがあるという。ぬた入院 中マリクロン（脳下垂体後烡製剂）注射に上り発作方誘 登された。すなわち利尿が括さえられることによつて發 作が誘發されたものと思和れる。

水試驗成續は症例 11,15 と注ડ゙同様で䏠量発作・利尿 抑制が括こつた。患者恃当時特直発腿振が認められて いたが、このようにはつきりした胶量発作は2 ケ月振り のものであり水分負荷が誘因と思市れる（図5）.

图 5 症 例 16

笔作誘発 $(+)$, 排尿遅延 $(+)$ の例

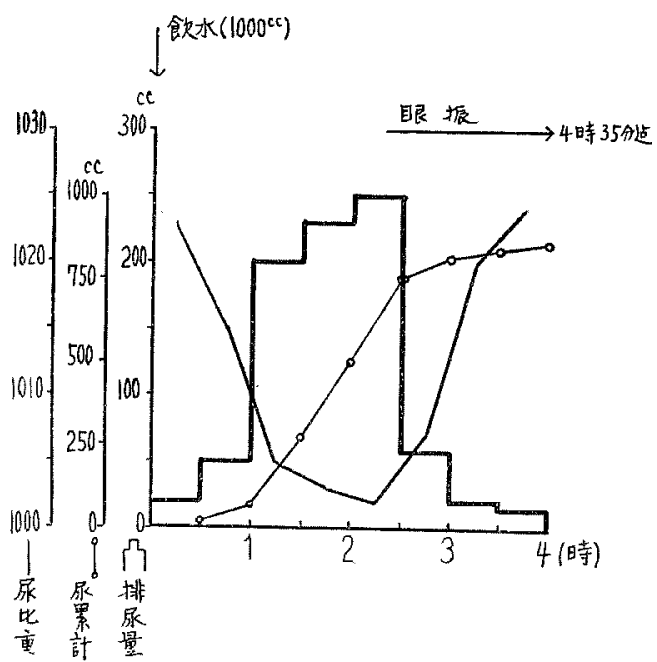

本例は入院以来硫酸アトロピン・ブロバリン・エフル モン等を投与する一万減塩食缭法（食塩 1 日量 $2 \sim 3 g$ あ
るいは 3〜5g）を約 2 ケ月行い尿量が徐るに増加すると \るに症状孔漸㳄改善して退院した．しかし体重はが つて増加している(図6).

図 6 症例 16 減塩食による尿量及び伡量の変動

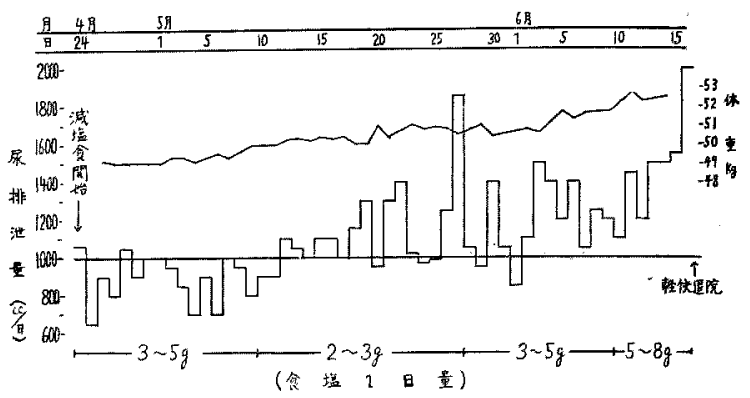

5. 考按

以上 20 例の観察から水分負荷水上り瞱最・耳鳴增強 等発作の誘発されらること，叔よび水分排泪遅延のみら れるものがあること知つた。これらの現象の頻度型

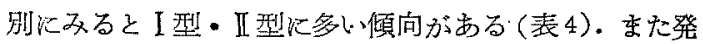
作誘発注自発眼层の認められたものに多い(表5). 排尿 幄延性主として発作誘発例隹められた（表б）。

表 4 発作誘発更び排尿逮延の型别頻度

\begin{tabular}{|c|c|c|c|c|c|c|}
\hline 犁 & 不完全 & 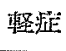 & I & II & III & 計 \\
\hline 発作誘発的り & 0例 & $1 \%$ & $3 "$ & $4 \%$ & $0 "$ & 8例 \\
\hline 発作䅇発なし & $2 "$ & 1 , & $4 \prime$ & 31 & $2 "$ & 12例 \\
\hline 排尿遲延あり & $0 \%$ & $0 "$ & $1 \%$ & $3 \%$ & $0 "$ & 4例 \\
\hline 排尿溇死侣し & $2 "$ & $2 \%$ & $6 \%$ & $4 "$ & $2 "$ & 16例 \\
\hline
\end{tabular}

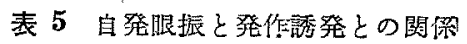

\begin{tabular}{|c|c|c|}
\hline & 自発腿振出v & 自発限振にし \\
\hline 発作誘笔出り & 6 例 & 2 例 \\
\hline 発作請登発いし & 1 例 & 11 例 \\
\hline
\end{tabular}

表 6 発作誘発と排尿逮延との関深

\begin{tabular}{|c|c|c|}
\hline & 発作誘発声り & 発作誘発沉し \\
\hline 排尿逮延出り & 3 例 & 1 例 \\
\hline 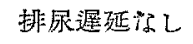 & 4 例 & 12 例 \\
\hline
\end{tabular}

さて水分珼荷により Mygind らのい5ごとく内耳生 が上笔するため発作が誘発されるのか，山るいは水分 負荷は単なる非特異的な誘因であるのか不明であるが 
Mygind らの説が 正しいとすれば内耳血管の透過性の 元進むるい性の特暴な内耳病変の存在が教えられる。 そこで典型的な発作を起した症例 15，16，17 kついてさ らに检訂してみると3例共通なことは過去に中联を 経過していることで豉膜所見は図 7 のごとく強い後遺症 を諗め，聴力は高度の混合性難聴を示している.Crowe 3) 注慢性中耳炎から限局性内耳炎を起し螖牛管と正师

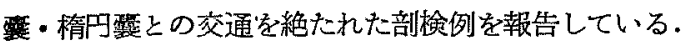
また㽘替・北山活) によると中耳炎から内耳に潜行的に 病変の波及する可能性があるといら，これらのことを孝 え合世ると前記 3 例にる内耳になんらかの不可逆性の器 質的病変があり，それが発作の誘発汇関保しているとも 推察される.

図 7 典㤠的発作誘発例の鼓膜所見

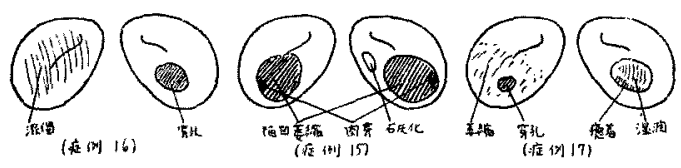

次に排尿迤延をきたす因子としては次の2つの因子が 考光られる・すなわち

1）×氏症候患者化もとをと利尿抑制傾向のある場合，

2).水分負荷に上り誘発された眩最発作のため二次的 に利尿が抑制される場合.

20 例中大部分汇利尿が良好であつたので,すべてのメ 氏症候患者にもとも利尿抑制傾向があるとは勿諭考完 られない.排尿逮延をきたした例はいずれる強い発作を

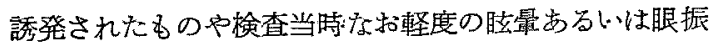
を認め迷路刺激から解放されていないるの>多いII型に 属する例である・またそれらの図について検討すると発 作の起る前から利尿が和さえられているが発作の起つた あと急澈な尿量減少が起つている・ぬた患者のながは 症例 $13 ， 16$ のごとく自然発作が标さまつたのりに多尿を 認める(多尿があつてから発作が扣さむるのではない)

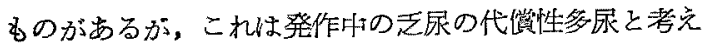
られる。これらの事実から 1)牤よび2）のいずれの場

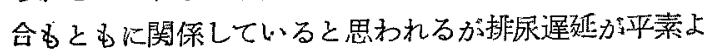
り迷路刺激から解放されていないと教えられる症例化主 として認められることから 1) の場合る李た迷路刺激の 二次的結果である可能性がある。

しかしで水分負荷あるいは利尿を抑制することによつ

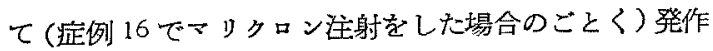
を誘発せしめうることも事実であるので迷路刺激と利尿

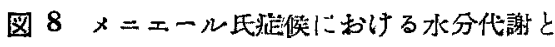

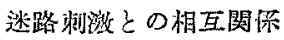

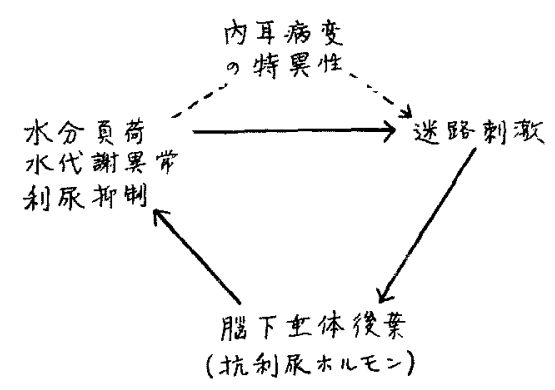

抑制とは互に因となり果となつて悪循環を形成している 々思呩れる(図8).

さて利尿を抑制された場合乞の水分の運命が問題とな るが、利尿を抑制された例子含めて体重は皆減少してお り増加したものは1例もなかつた。従つて負荷された水 分は4 時間以内になんらかの方法で体外飞排沮されたの であつて，局所はともかく全身的《は水分貯溜傾向があ るとは考えられない，症例 16 は減塩食により尿量が増 加し軽快したが体重はかえって增加しているので，やは り利尿の衰かつた時期にも恐らく全身的な水分䝪溜傾向 はなかつたのではなからうか。すなわらメ氏症候患者で は他に特殊な浮僆をきたす原因のないかぎり法尿が認め

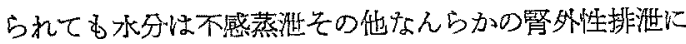
より排泄されるものと思れれる。

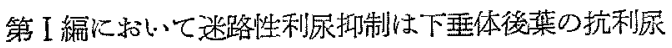
ホルモンによるものではないかとの結論をえたが，利尿 の抑制された症例 12 と利尿良好であつた症例 18 亿下垂 体後葉製成 マリタロン（1cc）索注射して比較してみる と，後者では利良抑制が認められたが前者では注射しな いときとその型に本質的な相違がみいだせなかつた 图 9 (A)，(B)). 前者ではあらかじめ充分な後集ホルモン が作用していたのではないかと教えられる・水と後葉木

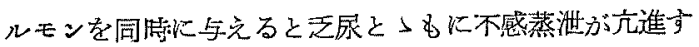
るというが,マリクロンを投与したこれらの例でもまた 前記のごとく利尿抑制の認みられたメ氏应候患者におい ても体重の増加はみられなからた。

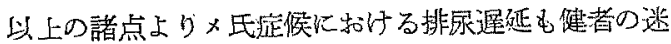
路刺激によつて認められた利尿抑制之同じ性質のもので ありやはり下垂体後葉の抗利尿小ルモン方関与してい るものと思われる。

血清中の抗利尿水ルモンの增加はその遊雒の促准なら びに非活性化の低下によつて起りらるが，非活性化には 
図 9 (A) 莎例 12

图 9 (B) 淽例 18

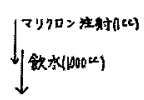
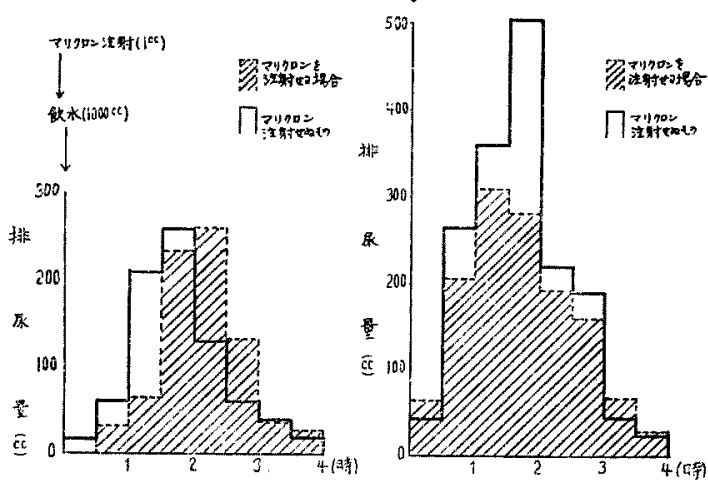

副腎皮質ホルモンが必要であるとい5．またこのホルモ ンは塩類代謝を介して 水分代謝に影唯を与える. Rey-

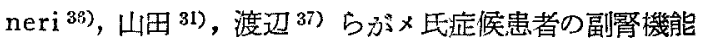
低下について報告し，また Perlmann ${ }^{30)}$ は Adison

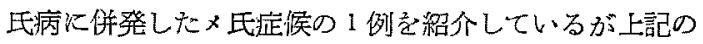

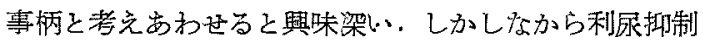
の強さから考えて消極的な非活性化の低下のみでなく邀 離の促進も当然起つているものと思わ机る。

水分代謝の機序はきわ和複雑で㐫り尿生成に関与す

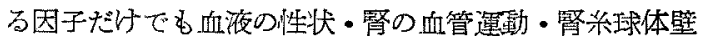
の透過性・腎細尿管つ再吸収などがあり，これらはさら

\section{III 結}

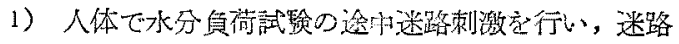

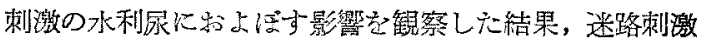
が抗利展作用を有すること学知つた。特に廷轱中首振り

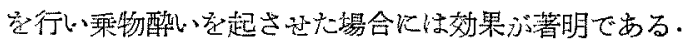

2）同時火観察した尿中内因桦タレアチニン量ならび に血清抗利尿活尘底などふら，この迷路性抗利尿作用は 主として血清中の抗利尿物質の増加による督細尿管より の水分再吸収の增進にもとすくるのと暂えられる。

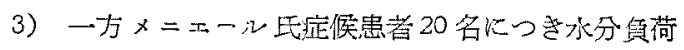

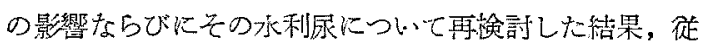

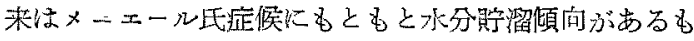

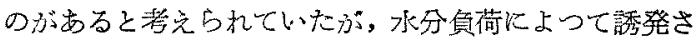

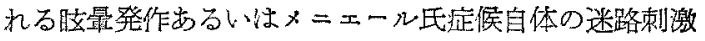

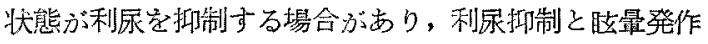
あるいは迷路束激とは互心因果関係を有し一つの悪循環 を形成していることを知つた。
に自律神経系・下垂体後葉，副腎皮質，甲状腺などの水 ルモンによつて影響を受けている・従つて今後さらに多 方面加らの総合的な捡討を要するあのと思われるが，以 上述べたことく，著者は大氏应候の適当な臨床的分類を 行い,さらに迷路刺激自体の利尿抑制効果を証明するこ とによつて，徉来全く混乱していた水分代謝とメ毛应候 この間に，明らかな相互的因果関係（臨床的には一氀の 悪循環）がみいだされたと考光るので敢えてこつに報告 した次第である。

\section{6. 小 括}

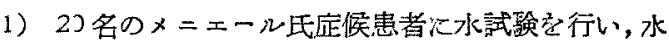
分負荷の影響ならびに利尿状態を锶察した。

2）水分負荷儿より㛺昱々の他の発作の誘発された马 のが7例，利尿の悪かつたるのが4例方った。

3）発作誘発括よび排尿遅延は主として週期的反稪型 および不規則重症型に認められた・

4）体雷方欴水4 時間後に, 增加したものは 1 例もな ふつた。

5）媤加減退をばつきり示したものもなかつた・

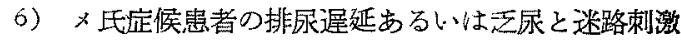
とは互に悪循嘌を形成しているものであり，第I編の実 験成績にもとずいて，その排尿遅延の成因には脳下垂体 後莎つ杭利尿ホルヒンが関与しているですらうと論し張 妾.

輪

\section{参考文 献}

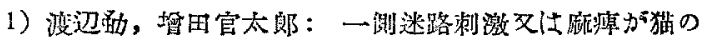

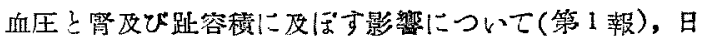

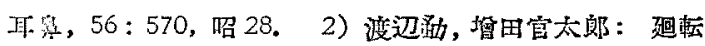

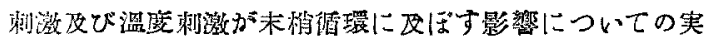

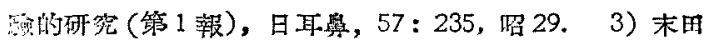
积：連綂的振動が生理的現象に及ぼす影繁に就いての

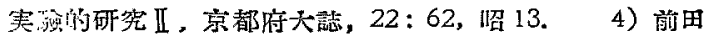

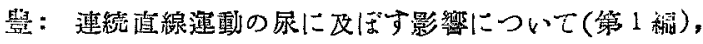
日㚎突，50：326，沼 19. 5) F.R. Stauffer \& E.O. Errebo-Knudsen: Positive Acceleration and Urine Output. J. Aviation Med. $21: 500,1950$. 6) F.R. Stauffer: Radial Acceleration and the Urinary Output of spinated Man. J. Aviation Med. 22: 391，1951. 7) 太田重夫：血源及び尿中タレアチ二 ン体の測定方法について，楫棠医学会誌，58：406，昭 


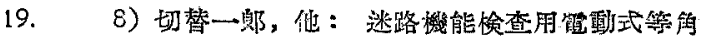
加速度迴枟装置!ついて, 医科器䙘学誌, 26:4, 昭 31 .

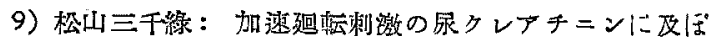
す影锌, 日耳鼻, 59:557, 炤 31. 10）W.H. Johnson et al: Stimulus Required to Produce Motion Sickness. 1. Preliminary Peport Dealing with Importance of Head Movement. J. Aviation Med. $22: 365,1951$.

11) D. Hofmann-Credner: Die

Beeinflussung der Wasserdiurese beim Menschen durch Flackerlicht. Helvetica medica acta. 20: Fasc. 1, 1953. 12) Sartorius et al: Endcrinology. 45.275, 1949.13）大圆茂卧：抗利尿木儿 モンの研究（1）, 日外会誌，56:214, 炤 30 .

Fulton: Textbook of Physiology, 863 (J.R. Elkinson: Physiology of Body Fluid). 15) C.S. Hallpike \& H. Cairns: Observation on the $\mathrm{Pa}$ thology of Ménière's Disease. J. Laryng. \& Otolog. 53:625, 1938. 16) H. Rollin: Zur Kenntnis des Labyrinthydrops und des durch ihn bedingten Ménière. Hals-Nasen-u. Ohrenargt. $31: 73$,

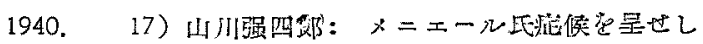

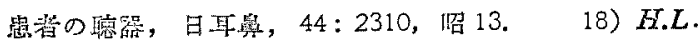
Williams et a!: Endolymphatic Hydrops without Vertigo; Its Differental Diagnosis and Treatment. Arch. Otolaryng. 51. 557, 1950. 19) S.H. Mygind: The Function and Diseases of the Labyrinth. Acta Otolaryng. 41. 235, 1952 . 20) D. Dederding: Clinical and Experimental Examinations in Patients Suffering from Mb. Menieri. Acta Otolaryng. Suppl. 10 11, 1929. 21) S.H. Mygind \& D. Dederding: The Significance of Water Metabolism in General Pathology as Demonstrated by Experiments on the Ear. Acta Otolaryng. 17 ; 424, $1932 . \quad$ 22) S.H. Mygind \& D. Dederding: Les Syndromes Meniériques (Monographie). Oto-rhino-laryng. Internat. No.26, 1934. 23) S.H. Mygind \& D. Dederding: Ménière's Disease, Clinical Experiments with Reference to the Influence of Water Metabolism on the Ear. Anv. Otol., Rhin. \& Laryng. 47:360, $1938 ; 47=55,1938 . \quad$ 24) B. Elmenhoff-Nielsen: Untersuchungen über Kapillarresistenzen bei Morbus Ménieri. Acta Otolaryng. 16: 415, 1931.
25) F. Eeugene: A New Concept of Ménière's Disease and its Response to Antiretentional Therapy. Am. J. Digest. Dis. \& Nutrition. 2: 243, 1935. 26) T. Cawthorne \& M.N. Fawcett: Fluid Balance in Ménière's Disease. Lancet. 2 : 1404, 1938. 27) A.C. Furstenberg, Lashmet \& Lathrop: Ménière's Symptomen Complex: Medical Threatment. Ann. Oto., Rhin. \& Laryng. 43; 1035, $1934 . \quad 28)$ M.R. Brown: The Medical Threatment of Méniére's Syndrome. J.A.M.A. 108: 1158, 1937. 29) J.H. Talbott \& M.R. Brown: Ménière's Syndrome. Acid-Base Constituents of the Blood: Treatment with Potasium Chloride. 30) H.B. Perlman, J.M. Goldinger \& J.O. Cales: Electrolyte Studies in Ménière's Disease. Laryngoscope. $63: 640,1953$. 31) 山田喜郎, 他: $x=$

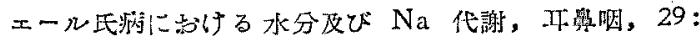
19, 嚾 32. 32）湾辺预, 他：

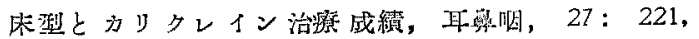

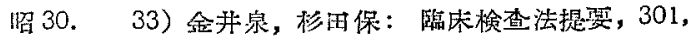
炤 24. 34) S.T. Crowe: Year Book of Eye, Ear, Nose \& Throat, 1949. 35) 切智一郎, 他: 中耳

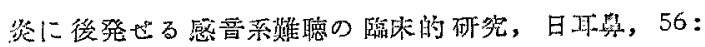
429, 怊28. 36) P. Reyneri: Il Test di Thorn nelle angioneurosi labirinche (Die Probe nach Thorn bei Angioneurosen des Labyrinthes) Minerva Otorinolaryng. 3: 77 (Zbl.f. Hals-usw. Heilk.) 49:65, 1954. 37) 淮辺勈, 他 : $x=x-$

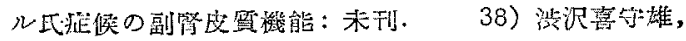

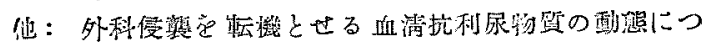

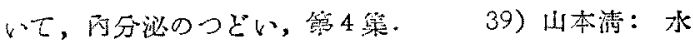

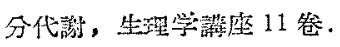

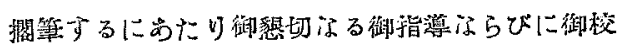

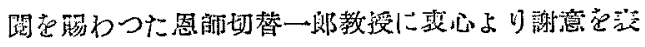

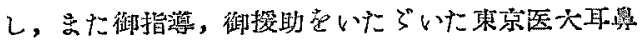

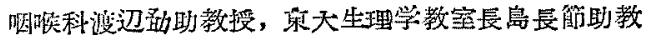

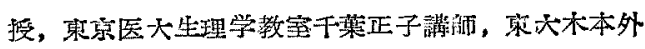

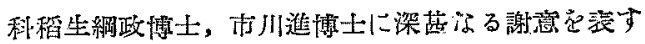

また本研究に種々御㔹力下さつた小倉，鉻木学士 に感謝する。

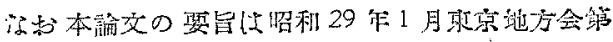

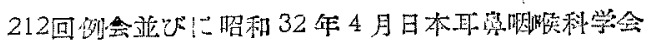

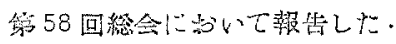

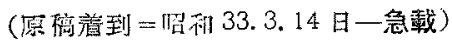

